\title{
Characteristics of physico-chemical properties, volatile compounds and free fatty acid profiles of commercial set-type Turkish yoghurts
}

\author{
Chemical properties of Turkish yoghurts
}

Zehra Güler ${ }^{1}$, Young W. Park ${ }^{2^{*}}$

${ }^{1}$ Department of Food Engineering, Mustafa Kemal University, 31034-Antakya-Hatay, TURKEY

${ }^{2}$ Agricultural Research Station, Fort Valley State University, Fort Valley, GA 31030, USA; parky@ fvsu.edu

Received March 25,2011;revised April 25,2011;accepted April 30,2011

\begin{abstract}
Ten most popular brands of commercial Turkish set-type yoghurts were collected from local retail outlets in Hatay, Turkey for two separate periods, and analyzed for basic nutrients, physico-chemical properties, volatile aroma compounds and free fatty acid profiles to compare their differences among the yoghurt products. The results showed that there were significant differences $(P<0.05,0.01$, or 0.001$)$ and variations in physico-chemical indices, volatile aroma compounds and volatile free fatty acid profiles among the yoghurt brands, which ultimately influence the flavor quality of the product. Acetaldehyde was predominant volatile compound in yoghurts, which followed by acetone, acetoin, diacetyl and ethanol. The level of diacetly was inversely related to titratable acidity, acetaldehyde and ethanoic acid. From ketones with high carbones 2-undecanone and 2-pentadecanone were higher than 2-butanone, 2-nanonane and 2-tridecanone. These ketones are related to fat content of yoghurt. Among short chain free fatty acids, ethanoic (acetic) acid was the most abundant in yoghurts, followed by hexanoic, octanoic and butanoic acids. These differences in detected chemical compositions of volatile compounds and free fatty acids would be applicable to predict flavor, nutritional value, quality control or shelf-life of the commmercial set-type Turkish yoghurts.
\end{abstract}

Keywords: Turkish Yoghurt; Free Fatty Acids; Volatile Compounds; Physico-Chemical Properties

\section{INTRODUCTION}

Yoghurt has been increasingly popular in many parts of the world, especially in Europe, North America and the Middle East. High consumption and popularity of yoghurt especially among women, children and teenagers are due to its nutritional and health benefits (Park, 1994; Hekmat and McMahon, 1997).

Although the origin of yoghurt is not definitely known, historical records indicate that the origin of yoghurt was in the Middle East (Tamime and Robinson, 2001) and it was first made by Turks when they were in Middle Asia and it was named as "yoghurt"(Tamime and Deeth, 1980). Today, the product has gained international recognition with this word, and many other countries use "yoghurt".

Streptococcus thermophilus and Lactobacillus delbrueckii subsp.bulgaricus are the two typical strains used for yoghurt production. The role of these two starter bacteria in yoghurt manufacture can be summarized as milk acidification and synthesis of aromatic compounds. Flavor compounds that contribute to the final aroma of yoghurt may be divided into four categories: non-volatile acids (lactic or pyruvic), volatile acids (butyric or acetic), carbonyl compounds (acetaldehyde or diacetyl) and miscellaneous compounds (amino acids or products formed by thermal degradation) (Tamime and Robinson, 2001). These flavor compounds of yoghurt are influenced by the chemical composition of milk base, processing conditions (e.g. heat treatment, homogenization), the ratio, activity and strains of starter culture used and incubation period (Beshkova et al.,1988; Kneifel et al.,1992; Ulbert and Kniefel, 1992; Hassan et al., 2003). In general, the overall properties of yoghurt, such as acidity level, free fatty acid (FFA) content, the production of aroma compounds (acetaldehyde, diacetly, 
acetoin) as well as the sensory profile, and nutritional value, are important traits of products.

In the Turkish markets, set-style yoghurts account for almost $100 \%$ of consumption. In set-style yoghurts, fermentation takes place in the final pots, so they are subjected to less industrial handling, and the possibility of contamination is lower. In Turkey, yoghurt is one of the greatest volumes of dairy products produced, which is 1010000 tons/per year (FAO, 2006). The consumers prefer yoghurts of different brands due to their different flavor and texture. However, few studies have been conducted on characterization of nutritional and chemical specifications of different commercial yoghurt products sold in Turkey.

Therefore the objectives of this study were to: (1) determine basic nutrient composition and some physicochemical characteristics of commercially marketed Turkish yoghurts, (2) quantify volatile compound and free fatty acid compositions of the products, and (3) evaluate the relationships among the tested parameters.

\section{MATERIAL AND METHODS}

\subsection{Preparation of Experimental Yoghurt Samples}

Two lots of set-type yoghurts made from cow milk were obtained from 10 most popular commercially marketed brands in Hatay, Turkey marketed during two separate periods in March and December, 2007.

\subsection{Chemical Analyses}

\subsubsection{Analyses of Basic Nutrients And Physicochemical Indices}

Total solids, fat, protein, ash contents and titratable acidity value of yoghurts were determined according to the Association of Official Analytical Chemist (AOAC, 2003) methods. $\mathrm{pH}$ was measured using a $\mathrm{pH}$ meter (Orion, Thermo, Austin, TX, USA). Lactose content was estimated as the difference between total solids and the sum of fat, protein and ash contents.

Color characterisitcs were measured by using a Minolta Chromameter (model CR-400 Tokyo, Japan) calibrated with a manufacturer-supplied white calibration plate. The $L$ (dark $=0$ and light $=100), a$ (red $=+a$ and green $=-a$ ) and $b$ (yellow $=+b$ and blue $=$ $-b$ ) values were measured. The $L^{*}, a^{*}$ and $b^{*}$ reading was carried out in triplicate for each sample. Results were expressed as Chroma $\left(C^{*}=\left[\left(a^{*}\right)^{2}+\left(b^{*}\right)^{2}\right]^{0.5}\right)$, hue angle $\left(h_{\mathrm{ab}}=\tan ^{-1}\left[\left(a^{*}\right)\left(b^{*}\right)^{-1}\right]\right)$, and whiteness in$\operatorname{dex}\left(W I=100-\left[(100-L)^{2}+a^{2}+b^{2}\right]^{0.5}\right)$. Analyses were carried out in duplicate obtaining two yoghurt samples from each brand were collected during two experimental period (March and December, 2007), and each sample was analyzed in duplicate.

\subsubsection{Analyses of Free Fatty Acids (Ffa) and Benzoic Acid}

Extraction and quantification of FFA and benzoic acid were carried out according to the method of Deeth et al. (1983) with slight modifications as reported by Güler (2008). Heptanoic acid was added to all experimental yoghurt samples at the time of extraction. FFAs were analyzed by a GC-MS (Agilent 6890 gas chromatograph and $5973 \mathrm{~N}$ mass selective detector; Agilent, Palo Alto, CA, USA). Column used for FFA and benzoic acid separation was a DB-FFAP-column $(30 \mathrm{~m} \times 0.25 \mathrm{~mm}$ id $\times$ $0.25 \mu \mathrm{m}$ film thickness). Analyses were carried out in triplicate.

For GC operating conditions of FFA and benzoic acid analysis, helium was used as a carrier gas with a constant flow rate of $1 \mathrm{~mL} \cdot \mathrm{min}^{-1}$. The $\mathrm{GC}$ oven temperature was set to $50^{\circ} \mathrm{C}$ for $5 \mathrm{~min}$ then raised to $230^{\circ} \mathrm{C}$ at a rate of $5^{\circ} \mathrm{C} \mathrm{min}{ }^{-1}$ and held at $230^{\circ} \mathrm{C}$ for $20 \mathrm{~min}$. The injector temperature was $250^{\circ} \mathrm{C}$, and the run time was 58 min. The GC column was connected without splitting to the ion source of the Agilent 5973N model quadrupole mass selective detector which was operating in the scan mode within a mass range 33 to $330 \mathrm{~m} \mathrm{z}^{-1}$ at $1 \mathrm{scan} \mathrm{s}^{-1}$. The interface line to MS was set at $280^{\circ} \mathrm{C}$. The MS was ope- rated in an electron impact mode at electron energy of $70 \mathrm{eV}$ and was calibrated by auto-tuning. Identification of the compounds was performed by a computermatching of their mass spectral data with those of known compounds from the Mass Spectral Database (Wiley7n.1/Nist02.L.). To compensate the amount of loss during the extraction and clean-up, heptanoic acid $\left(\mathrm{C}_{7}\right)$ was used as internal standard. Pre-analyses of the milk and yoghurt had ensured that heptanoic acid was absent.

\subsubsection{Analysis of Volatile Compounds (VC)}

VCs were determined by static head space technique according to Güler (2007). VCs were analyzed using a Agilent model 6890 gas chromatography (GC) and 5973 $\mathrm{N}$ mass selective detector (MS) (Agilent, Palo Alto, CA, USA). Columns used for FFA separation HP- INNOWAX capillary column $(30 \mathrm{~m} \times 0.32 \mathrm{~mm}$ id $\times 0.25 \mu \mathrm{m}$ film thickness). The volatile compounds were separated under the following conditions: injector temperature $200^{\circ} \mathrm{C}$; carrier gas helium at a flow rate of $1.4 \mathrm{~mL} \cdot \mathrm{min}^{-1}$; oven temperature program initially held at $50^{\circ} \mathrm{C}$ for $6 \mathrm{~min}$ and then programmed from $50^{\circ} \mathrm{C}$ to $180^{\circ} \mathrm{C}$ at $8^{\circ} \mathrm{C} \cdot \mathrm{min}^{-1}$ held at $180^{\circ} \mathrm{C}$ for $5 \mathrm{~min}$. The interface line to MS was set at $250^{\circ} \mathrm{C}$. Identification of the compounds was also conducted by a computermatching of their mass spectral 
data with those of known compounds from the Nist 02.L. Mass Spectral Database. Based on the peak resolution, their areas were estimated from the integrations performed on selected ions. The resulting peak areas were expressed in the arbitrary area units. Quantification of constituents was calculated by external standard technique.

\subsection{Statistical Analysis}

Statistical analysis was performed using the SPSS version 9.05 for Macintosh (SPPSS Inc./Chicago, III., U.S.A.). Physicochemical parameters were submitted to one-way analysis of variance (ANOVA). Duncan multiple mean comparison test $(\mathrm{P}<0.05)$ was used to state the differences among the brands. Principal component analysis (PCA), using a correlation matrix, was carried out on mean of chemical compounds including volatiles, free fatty acids. PCA is a statistical technique used to identify the minimum number of latent variables, called 'principal components', that explain the highest amount of observed variability among studied samples. This technique simplifies the initial multidimensional data matrix without the loss of any important information, thus making results easier to interpret.

To simplify the interpretation of results, flavor, physical properties and volatile compounds were studied separately. Varimax rotation was performed on variables. Eigenvalues over 1.0 were considered as the selection criterion for the minimum number of components. Correlation analysis was also performed to determine relationships among individual physicochemical parameter, FFA and volatile compounds in the yoghurt samples.

\section{RESULTS AND DISCUSSION}

\subsection{Physicochemical Characteristics}

Characteristics of basic nutrient composition and physico-chemical parameters of 10 most popular Turkish yoghurts are summarized and compared in Table 1. The mean values for total solids, fat, protein, ash, titratable acidity and $\mathrm{pH}$ were $15.30 \%, 3.77 \%, 4.88 \%, 0.99 \%$, $1.58 \%$ (lactic acid) and 4.22 , respectively. The mean total solids, fat and titratable acidity of yoghurts were within the range of Turkish yoghurt standard, which were > $15.5 \pm 0.5 \%, 1.5 \%-3.8 \%<$ and $0.6 \%-1.6 \%$ (lactic acid), respectively. As shown in Table 1, there were significant differences $(\mathrm{P}<0.05,0.01$ and 0.001$)$ in physicochemical properties between the 10 yoghurts tested. Titratable acidity values of yoghurts obtained from brands AS, SK, TV and YR were slightly high than maximum level (1.6\% lactic acid) reported in Turkish standard, while that of the other samples was close to the standard level. High titratable acidity is not suprising since yoghurts are characterized primarily by its acidity. Titratable acidity is one of the most important parameters with respect to the shelf-life of fermented milk products and also a reasonable indication of the performance of the starter culture (Tamime and Robinson, 2001). High titratable acidity in yoghurts is probably due to high total solids content, especially in protein since titratable acidity was positively correlated to total solids (0.632, $\mathrm{P}<0.01)$ and protein $(0.533, \mathrm{P}<0.01)$. According to Turkish yoghurt standard (TSI, 2006), yoghurts AS, SK, TV and YR are classified as whole milk-yoghurt $(3.8 \%$ fat $<)$ and the other samples were classified as fat-yoghurt. The chemical characteristics of Turkish yoghurts are different from values reported by Tamime and Robinson (2001). This may be attributed to the yoghurt-making technique since corn starch in most countries is used in natural yoghurt maufacture for the fortification of milk or sweet flavor. These yoghurts would have a low fat and high carbohydrate contents. For natural yoghurt-making, the use of some ingredients is forbidden by Turkish reguations. Traditionally, it is known that Turkish people prefer sour yoghurt flavor.

Characteristics of yoghurt color is another important marketable (consumer acceptance) quality attribute.

Table 1. Mean basic nutrient content (g/100 g yoghurt) and physico-chemical indices of 10 brands of commercial Turkish set-type yoghurts ${ }^{1}$.

\begin{tabular}{|c|c|c|c|c|c|c|c|c|c|c|c|}
\hline \multirow[b]{2}{*}{ Properties } & \multicolumn{10}{|c|}{ Brands } & \multirow[b]{2}{*}{$P$} \\
\hline & AK & AS & DN & DS & $\mathrm{IC}$ & PN & SK & ST & TV & YR & \\
\hline $\mathrm{TS}^{2}$ & $15.19 \pm 0.62^{b}$ & $15.79 \pm 0.26^{\mathrm{bc}}$ & $13.16 \pm 1.09^{\mathrm{a}}$ & $15.07 \pm 0.42^{b}$ & $14.82 \pm 0.13^{b}$ & $15.00 \pm 0.57^{b}$ & $15.64 \pm 0.04^{\mathrm{bc}}$ & $15.15 \pm 0.05^{b}$ & $16.46 \pm 1.47^{\mathrm{cd}}$ & $16.72 \pm 0.41^{\mathrm{d}}$ & *** \\
\hline Protein & $5.24 \pm 0.54^{b c}$ & $4.82 \pm 0.33^{\mathrm{ab}}$ & $4.64 \pm 0.84^{\mathrm{ab}}$ & $4.85 \pm 0.41^{\mathrm{ab}}$ & $4.55 \pm 0.57^{\mathrm{ab}}$ & $4.77 \pm 0.51^{\mathrm{ab}}$ & $4.36 \pm 0.27^{\mathrm{ab}}$ & $4.13 \pm 0.47^{\mathrm{a}}$ & $5.91 \pm 1.21^{\mathrm{c}}$ & $5.32 \pm 0.44^{b c}$ & $*$ \\
\hline Fat & $3.50 \pm 0.12^{\mathrm{a}}$ & $5.35 \pm 0.06^{\mathrm{d}}$ & $3.35 \pm 0.19^{\mathrm{a}}$ & $3.35 \pm 0.19^{\mathrm{a}}$ & $3.55 \pm 0.10^{\mathrm{a}}$ & $3.48 \pm .22^{\mathrm{a}}$ & $3.65 \pm 0.17^{\mathrm{ab}}$ & $3.30 \pm 0.23^{\mathrm{a}}$ & $4.18 \pm 0.17^{\mathrm{c}}$ & $3.95 \pm 0.50^{\mathrm{bc}}$ & $* *$ \\
\hline Lactose & $5.45 \pm 0.29^{\mathrm{ab}}$ & $4.66 \pm 0.42^{\mathrm{ab}}$ & $4.38 \pm 1.80^{\mathrm{a}}$ & $5.97 \pm 0.45^{\mathrm{bc}}$ & $5.80 \pm 0.74^{\mathrm{bc}}$ & $5.90 \pm 0.54^{b c}$ & $6.75 \pm 0.38^{\mathrm{cd}}$ & $6.82 \pm 0.71^{\mathrm{d}}$ & $5.16 \pm 0.49^{\mathrm{ab}}$ & $6.51 \pm 1.16^{\mathrm{cd}}$ & $* *$ \\
\hline Ash & $1.01 \pm 0.02^{\mathrm{e}}$ & $0.96 \pm 0.00^{\mathrm{de}}$ & $0.79 \pm 0.08^{\mathrm{a}}$ & $0.90 \pm 0.02^{\mathrm{bc}}$ & $0.91 \pm 0.03^{\mathrm{cd}}$ & $0.85 \pm 0.06^{\mathrm{b}}$ & $0.88 \pm 0.01^{\mathrm{bc}}$ & $0.90 \pm 0.01^{\mathrm{bc}}$ & $0.96 \pm 0.01^{\mathrm{de}}$ & $0.93 \pm 0.01^{\mathrm{cd}}$ & $* * *$ \\
\hline $\mathrm{pH}$ & $4.51 \pm 0.07^{\mathrm{c}}$ & $4.18 \pm 0.07^{\mathrm{ab}}$ & $4.18 \pm 0.23^{\mathrm{ab}}$ & $\pm 0.10^{\mathrm{ab}}$ & $35 \pm 0.19^{\mathrm{bc}}$ & $4.22 \pm 0.10^{\mathrm{ab}}$ & $4.07 \pm 0.16^{\mathrm{a}}$ & $4.23 \pm 0.25^{\mathrm{ab}}$ & $4.05 \pm 0.04^{\mathrm{a}}$ & $4.25 \pm 0.16^{\mathrm{ab}}$ & $* *$ \\
\hline $\mathrm{TA}^{3}$ & $1.43 \pm 0.03^{\mathrm{ab}}$ & $1.72 \pm 0.01^{\mathrm{ef}}$ & $1.37 \pm 0.02^{\mathrm{a}}$ & $1.60 \pm 0.05^{\mathrm{d}}$ & $1.42 \pm 0.02^{\mathrm{ab}}$ & $1.57 \pm 0.09^{\mathrm{cd}}$ & $1.77 \pm 0.05$ & $1.49 \pm 0.12^{\mathrm{bc}}$ & $1.83 \pm 0.02^{\mathrm{f}}$ & $1.64 \pm 0.03^{\mathrm{de}}$ & $* * *$ \\
\hline Chroma & $7.38 \pm 0.2^{\mathrm{ab}}$ & $7.26 \pm 0.1^{\mathrm{a}}$ & $7.39 \pm 0.1^{\mathrm{ab}}$ & $7.69 \pm 0.1^{\mathrm{c}}$ & $7.66 \pm 0.08^{\mathrm{cd}}$ & $7.88 \pm 0.1^{\mathrm{d}}$ & $7.50 \pm 0.1^{\mathrm{b}}$ & $7.78 \pm 0.1^{\mathrm{d}}$ & $8.32 \pm 0.1^{\mathrm{e}}$ & $7.74 \pm 0.1^{\mathrm{d}}$ & * \\
\hline $\mathrm{HA}^{5}$ & $-25.25 \pm 0.2^{\mathrm{c}}$ & $-24.52 \pm 0.2^{\mathrm{cd}}$ & $-25.57 \pm 0.2^{\mathrm{c}}$ & $27.36 \pm 0.1^{\mathrm{b}}$ & $-27.13 \pm 0.23^{\mathrm{b}}$ & $-27.88 \pm 0.1^{\mathrm{b}}$ & $-25.56 \pm 0.2^{\mathrm{c}}$ & $-27.40 \pm 0.3^{\mathrm{b}}$ & $-30.20 \pm 0.2^{\mathrm{a}}$ & $-27.37 \pm 0.3^{\mathrm{b}}$ & * \\
\hline
\end{tabular}

${ }^{1}$ Each observation is mean \pm standard deviation of four yoghurt samples; ${ }^{2} \mathrm{TS}$ : Total solids; ${ }^{3} \mathrm{TA}$ : Titratable acidity; expressed as g lactic acid $100 \mathrm{~g}-1$ of yoghurt; ${ }^{4}$ WI: Whiteness index; ${ }^{5} \mathrm{HA}$ : Hue angle; a.b.c Means with different superscript within the same row are significantly different between yoghurt brands; P: Significance level. NS: non significant; $* \mathrm{P}<0.05, * * \mathrm{P}<0.01$, and $* * * \mathrm{P}<0.001$. 
Yoghurt color is a measure of whiteness index (WI, black $=0$ and white $=100)$, chroma $\left(C^{*}\right.$; color intensity $)$ and hue angle ( $h_{\mathrm{ab}}$; color purity). Whiteness index, chroma and $h_{\mathrm{ab}}$ values of samples varied from 77.57 to 7.25 and -30.20 to $78.72,8.32$ and -24.52 , respectively (Table 1). The whiteness index $(-0.594, \mathrm{P}<0.01)$ and $h_{\mathrm{ab}}$ $(0.360, \mathrm{P}<0.05)$ values of yoghurts were correlated to fat since higher $h_{\mathrm{ab}}$ is more yellow hue. Chroma (color intensity) was correlated to total solids $(0.360, \mathrm{P}<0.05)$ and protein $(0.318, \mathrm{P}<0.05)$. The color values of cow milk yoghurts in this study were different from the results observed for goat milk-yoghurt (Guler and Park, 2009) and for nonhomogenized cow milk yoghurt (Vargas et al., 2008). This apparently accounts for the type of milk used for yoghurt-making, the chemical composition of yoghurt and yoghurt-making technique since the gel opacity is related to the fat content, casein ratio and their aggregation level (Hutchings, 1999).

\subsection{Free Fatty Acids Profiles}

Free fatty acids (FFA) are generated by both lipolytic processes $\left(\mathrm{C}_{4}-\mathrm{C}_{20}\right)$ and bacterial fermentation $\left(\mathrm{C}_{2}-\mathrm{C}_{4}\right)$. Quantification of the levels of short-chain FFAs would be important since their concentration can cause flavor changes and defects in milk based foods. The results of our study (Table 2) showed that hexadecanoic $\left(\mathrm{C}_{16}\right)$, octadecanoic $\left(\mathrm{C}_{18}\right)$, cis 9-Octadodecanoic $\left(\mathrm{C}_{18: 1}\right)$, tetradecanoic $\left(\mathrm{C}_{14}\right)$, ethanoic acid $\left(\mathrm{C}_{2}\right)$, dodecanoic $\left(\mathrm{C}_{12}\right)$ and hexanoic $\left(\mathrm{C}_{6}\right)$ acids were the major FFAs found in the Turkish yoghurts. This outcome was similar to the previous report on cow milk yoghurts made with different types of cultures (Guler, 2008). There were significant differences $(\mathrm{P}<0.05,0.01$ and 0.001$)$ in $\mathrm{C}_{2}$ to $\mathrm{C}_{12}$ and $\mathrm{C}_{18}$ free fatty acids concentrations among different brands of the yoghurts.

Principal component analyses (PCA) applied to free fatty acids is shown in Table 3. Varimax rotation was applied to more clearly for grouping individual compounds. The compounds demonstrating the similar chemical properties and/or origin were grouped into the one component and were related to each other in proportion to the magnitude of their coefficients. The first component is the combination of variables that explains the greatest amount of variation. The second compound defines the next largest amount of variation. According to the PCA, the first three components explained $77.42 \%$ of the total variation. The first component, accounting for $33.39 \%$ of total variance, was an intense free fatty acid, with high loadings for butanoic, hexanoic, octanoic, decanoic and dodecanoic acids with positive coefficient, and octadecanoic and cis, 9-octadecenoic acid with negative coefficient. In other words, the $\mathrm{C}_{4}$ to $\mathrm{C}_{12}$ free fatty acids were negatively related to the different types of $\mathrm{C}_{18}$ fatty acids. This result was in consistent with the previous reports (Calderon et al.,1984; Lee et al., 2004). The second component, explaining $27.77 \%$ of total variance, was defined by tetradecanoic and hexadecanoic acids with positive correlations. The last component, accounting for $16.26 \%$ of total variance, was related to ethanoic acid with high negative coefficient. Ethanoic and benzoic acid too was seperately grouped from other free fatty acids. This result implies that acetic acid was not produced from only lipolysis by lipases, but from other biochemical pathways.

Among short chain free fatty acids, ethanoic (acetic) acid was the most abundant in yoghurts, followed by hexanoic, octanoic and butanoic acids. This result was

Table 2. Profiles of mean concentrations ( $\mu \mathrm{g} 100 \mathrm{~g}^{-1}$ of yoghurt) of free fatty acids and benzoic acid in 10 brands of Turkish commercial set-type yoghurts ${ }^{1}$.

\begin{tabular}{|c|c|c|c|c|c|c|c|c|c|c|c|}
\hline \multirow[b]{2}{*}{ Free Fatty Acids } & \multicolumn{10}{|c|}{ Brands } & \multirow[b]{2}{*}{$\mathrm{P}$} \\
\hline & $\mathrm{AK}$ & AS & $\mathrm{DN}$ & DS & IC & PN & SK & ST & TV & YR & \\
\hline Ethanoic $\left(\mathrm{C}_{2}\right)$ & $12.4 \pm 4.0^{\mathrm{ab}}$ & $23.8 \pm 8.1^{\mathrm{bc}}$ & $5.3 \pm 2.7^{\mathrm{a}}$ & $5.4 \pm 4.0^{\mathrm{a}}$ & $15.1 \pm 7.2^{\mathrm{ab}}$ & $3.3 \pm 2.8^{\mathrm{a}}$ & $8.5 \pm 5.3^{\mathrm{ab}}$ & $12.1 \pm 11.6^{\mathrm{ab}}$ & $13.9 \pm 2.3^{\mathrm{ab}}$ & $34.6 \pm 23.7^{\mathrm{c}}$ & *** \\
\hline Butanoic $\left(\mathrm{C}_{4}\right)$ & $6.3 \pm 3.8^{\mathrm{c}}$ & $9.1 \pm 6.1^{\mathrm{cd}}$ & $5.4 \pm 5.0^{\mathrm{b}}$ & $12.1 \pm 5.4^{\mathrm{e}}$ & $3.6 \pm 2.2^{\mathrm{ab}}$ & $4.5 \pm 2.1^{\mathrm{d}}$ & $8.6 \pm 9.3^{\mathrm{cd}}$ & $14.7 \pm 10.3^{\mathrm{f}}$ & $1.3 \pm 0.6^{\mathrm{a}}$ & $9.8 \pm 3.2^{\mathrm{cd}}$ & $* * *$ \\
\hline Hexanoic $\left(\mathrm{C}_{6}\right)$ & $9.2 \pm 5.3^{\mathrm{bc}}$ & $10.2 \pm 3.2^{\mathrm{cd}}$ & $3.9 \pm 3.2^{\mathrm{a}}$ & $16.2 \pm 12.2^{\mathrm{e}}$ & $9.5 \pm 7.4^{\mathrm{b}}$ & $5.9 \pm 2.9^{\mathrm{a}}$ & $9.0 \pm 11.2^{\mathrm{bc}}$ & $14.4 \pm 11.5^{\mathrm{e}}$ & $5.1 \pm 0.7^{\mathrm{a}}$ & $14.3 \pm 6.4^{\mathrm{d}}$ & *** \\
\hline Octanoic $\left(\mathrm{C}_{8}\right)$ & $2.2 \pm 0.4^{\mathrm{a}}$ & $2.1 \pm 0.4^{\mathrm{a}}$ & $4.5 \pm 2.0^{\mathrm{f}}$ & $3.4 \pm 6.1^{\mathrm{g}}$ & $6.4 \pm 5.0^{\mathrm{cd}}$ & $3.4 \pm 0.8^{\mathrm{ab}}$ & $4.6 \pm 2.9^{\mathrm{bc}}$ & $7.6 \pm 4.2^{\mathrm{e}}$ & $3.2 \pm 1.0^{\mathrm{ab}}$ & $5.8 \pm 1.3$ & **** \\
\hline Total $\left(\mathrm{C}_{2}-\mathrm{C}_{8}\right)$ & $30.1 \pm 13.6$ & $45.3 \pm 17.7$ & $19.1 \pm 13.0$ & $37.4 \pm 27.9$ & $34.6 \pm 22.0$ & $17.1 \pm 8.7$ & $30.7 \pm 28.7$ & $48.9 \pm 37.7$ & $23.59 \pm 4.74$ & $64.6 \pm 34.7$ & \\
\hline Decanoic $\left(\mathrm{C}_{10}\right)$ & $4.4 \pm 1.5^{\mathrm{a}}$ & $3.8 \pm 0.9^{\mathrm{bc}}$ & $10.4 \pm 4.1^{\mathrm{f}}$ & $6.4 \pm 5.2^{\mathrm{g}}$ & $8.4 \pm 3.6^{\mathrm{d}}$ & $5.9 \pm 0.9^{\mathrm{bc}}$ & $6.9 \pm 3.2^{\mathrm{cd}}$ & $11.2 \pm 5.2^{\mathrm{f}}$ & $6.9 \pm 2.6^{\mathrm{d}}$ & $8.8 \pm 3.2^{\mathrm{e}}$ & $* * *$ \\
\hline Dodecanoic $\left(\mathrm{C}_{12}\right)$ & $7.2 \pm 2.6^{\mathrm{a}}$ & $10.1 \pm 5.4^{\mathrm{bc}}$ & $15.7 \pm 4.8^{\mathrm{e}}$ & $10.4 \pm 17.2^{\mathrm{f}}$ & $10.7 \pm 4.0^{\mathrm{bc}}$ & $13.2 \pm 3.1^{\mathrm{e}}$ & $9.7 \pm 2.7^{\mathrm{bc}}$ & $11.6 \pm 4.3^{\mathrm{d}}$ & $8.8 \pm 3.8^{c}$ & $8.9 \pm 1.1^{\mathrm{b}}$ & *** \\
\hline Total $\left(\mathrm{C}_{10}-\mathrm{C}_{14}\right)$ & $47.3 \pm 16.4$ & $48.7 \pm 21.8$ & $74.9 \pm 23.1$ & $55.2 \pm 39.5$ & $67.2 \pm 16.2$ & $55.2 \pm 13.9$ & $54.3 \pm 11.3$ & $62.4 \pm 20.1$ & $55.6 \pm 18.6$ & $50.0 \pm 12.1$ & \\
\hline Pentadecanoic $\left(\mathrm{C}_{15}\right)$ & $3.0 \pm 0.7^{b}$ & $3.3 \pm 1.5^{b}$ & $6.2 \pm 3.6^{\mathrm{c}}$ & $1.6 \pm 1.9^{\mathrm{a}}$ & $5.8 \pm 1.7^{\mathrm{c}}$ & $3.6 \pm 1.7^{\mathrm{b}}$ & $2.4 \pm 1.8^{\mathrm{a}}$ & nd & $2.53 \pm 1.81^{b}$ & $2.9 \pm 1.1^{\mathrm{b}}$ & $* *$ \\
\hline Hexadecanoic $\left(\mathrm{C}_{16}\right)$ & $186.5 \pm 53.5$ & $158.2 \pm 68.1$ & $209.2 \pm 60.7$ & $170.5 \pm 81.0$ & $217.9 \pm 33.2$ & $183.9 \pm 41.3$ & $200.3 \pm 3.4$ & $198.7 \pm 21.1$ & $227.9 \pm 25.3$ & $153.3 \pm 51.5$ & NS \\
\hline 9-Hexadecenoic $\left(C_{16: 1}\right)$ & $\mathrm{Nd}$ & $\mathrm{Nd}$ & $2.9 \pm 1.9^{c}$ & $0.2 \pm 0.1^{\mathrm{a}}$ & $3.5 \pm 1.9^{\mathrm{c}}$ & $2.9 \pm 2.7^{\mathrm{c}}$ & $4.5 \pm 4.3^{\mathrm{d}}$ & $1.7 \pm 1.2^{\mathrm{b}}$ & $7.3 \pm 4.5^{\mathrm{e}}$ & nd & $*$ \\
\hline Heptadecanoic $\left(\mathrm{C}_{17}\right)$ & $4.4 \pm 1.8^{\mathrm{c}}$ & $\mathrm{Nd}$ & $2.6 \pm 0.4^{\mathrm{b}}$ & $\mathrm{Nd}$ & $6.1 \pm 1.7^{\mathrm{d}}$ & $3.1 \pm 2.3^{b}$ & $1.9 \pm 1.0^{\mathrm{a}}$ & $1.8 \pm 0.5^{\mathrm{a}}$ & $4.7 \pm 0.8^{\mathrm{c}}$ & $6.8 \pm 3.2^{\mathrm{d}}$ & $* *$ \\
\hline Octadecanoic $\left(\mathrm{C}_{18}\right)$ & $120.5 \pm 40.2^{\mathrm{bc}}$ & $88.6 \pm 40.9^{\mathrm{ab}}$ & $98.8 \pm 26.6^{\mathrm{abc}}$ & $78.5 \pm 42.6^{\mathrm{a}}$ & $111.9 \pm 29.8^{\mathrm{ab}}$ & $75.3 \pm 16.6$ & $141.2 \pm 31.0^{\mathrm{c}}$ & $144.5 \pm 44.1^{\mathrm{bc}}$ & $131.4 \pm 35.0^{\mathrm{bc}}$ & $75.5 \pm 28.1^{\mathrm{ab}}$ & $*$ \\
\hline 9-Octadecenoic $\left(\mathrm{C}_{18: 1}\right)$ & $88.6 \pm 48.1$ & $59.8 \pm 31.4$ & $73.1 \pm 26.0$ & $56.9 \pm 16.2$ & $80.7 \pm 31.7$ & $111.8 \pm 27.0$ & $64.9 \pm 7.4$ & $43.0 \pm 19.0$ & $99.3 \pm 18.0$ & $40.2 \pm 25.5$ & NS \\
\hline Total $\left(\mathrm{C}_{15-} \mathrm{C}_{18: 1}\right)$ & $405.9 \pm 146.9$ & $309.8 \pm 142.1$ & $392.8 \pm 119.4$ & $307.7 \pm 141.8$ & $3425.8 \pm 100.0$ & $380.6 \pm 1.9$ & $415.1 \pm 49.4$ & $388.5 \pm 86.5$ & $473.1 \pm 85.5$ & $278.6 \pm 109.5$ & \\
\hline
\end{tabular}

${ }^{1}$ Each observation is mean \pm standard deviation of four yoghurt samples; ${ }^{\text {a.b.c }}$ Means with different superscript within the same row were significantly different between yoghurt brands; $\mathrm{P}$ : significance level. NS: non significant; $* \mathrm{P}<0.05$, $* * \mathrm{P}<0.01$, and $* * * \mathrm{P}<0.001$. 
Table 3. Principle component loadings of free fatty acids in yoghurts following varimax rotation.

\begin{tabular}{lccc}
\hline & \multicolumn{3}{c}{ Principal Component } \\
\hline Free Fatty Acids & PC1 & PC2 & PC3 \\
\hline Ethanoic acid $\left(\mathrm{C}_{2}\right)$ & -0.14 & -0.38 & $\mathbf{0 . 7 2}$ \\
Butanoic acid $\left(\mathrm{C}_{4}\right)$ & $\mathbf{0 . 7 6}$ & 0.08 & 0.32 \\
Hexanoic acid $\left(\mathrm{C}_{6}\right)$ & $\mathbf{0 . 8 1}$ & 0.08 & 0.48 \\
Octanoic acid $\left(\mathrm{C}_{8}\right)$ & $\mathbf{0 . 8 3}$ & 0.48 & 0.09 \\
Decanoic acid $\left(\mathrm{C}_{10}\right)$ & $\mathbf{0 . 7 4}$ & 0.51 & -0.05 \\
Dodecanoic acid $\left(\mathrm{C}_{12}\right)$ & $\mathbf{0 . 6 9}$ & 0.41 & -0.42 \\
Tetradecanoic acid $\left(\mathrm{C}_{14}\right)$ & -0.32 & $\mathbf{0 . 7 3}$ & 0.05 \\
Pentadecanoic $\left(\mathrm{C}_{15}\right)$ & $\mathbf{0 . 6 6}$ & 0.09 & -0.50 \\
Hexadecanoic $\left(\mathrm{C}_{16}\right)$ & -0.51 & $\mathbf{0 . 8 1}$ & 0.19 \\
9-Hexadecenoic $\left(\mathrm{C}_{16: 1}\right)$ & $\mathbf{0 . 6 1}$ & 0.14 & 0.04 \\
Heptadecanoic $\left(\mathrm{C}_{17}\right)$ & $\mathbf{0 . 5 5}$ & 0.03 & 0.11 \\
Octadecanoic $\left(\mathrm{C}_{18}\right)$ & $\mathbf{0 . 5 1}$ & 0.40 & 0.38 \\
9-Octadecenoic $\left(\mathrm{C}_{18: 1}\right)$ & $\mathbf{0 . 6 8}$ & 0.49 & -0.04 \\
Benzoic acid & 0.14 & 0.10 & $\mathbf{0 . 8 3}$ \\
\% explained variance & 27.48 & 26.75 & 19.77 \\
\hline
\end{tabular}

Numbers in bold are primary importance due to the magnitude of coefficient.

consistent with that reported by the other authors (Rasic and Kurman, 1978; Warsy, 1983). Beshkova et al. (1998) found that the formation of volatile free fatty acids $\left(\mathrm{C}_{2}-\mathrm{C}_{10}\right)$ was more active in the mixed yoghurt cultures than in the pure ones owing to the stimulating effect of protocol-operation between the two thermophillic species on the metabolic activities, which are responsible for the formation of free fatty acids. In fact, volatile acids is not only produced from lipolysis by lipases but also from several biochemical pathways including the fermentation of lactose or citrate and the degradation (oxidative deamination or decarboxylation) of amino acids (alanine and serine) which are the most important precursor of most volatile fatty acids (Kneifel et al., 1992; Beshkova et al.,1998). The present study showed that butanoic $(0.396, \mathrm{P}<0.05)$, hexanoic $(0.423, \mathrm{P}<$ $0.01)$ and octanoic $(0.320, \mathrm{P}<0.05)$ acids were correlated to lactose content. Acetic acid was also positively correlated to total solids $(0.373, \mathrm{P}<0.05)$ and fat $(0.345$, $\mathrm{P}<0.05)$, where similar results were found by Kaminerides et al. (2007).

The short-, medium- and long-chain FFAs represented approximately $6.8-7.8,10.8-13.0$ and $82.2 \%-79.2 \%$, respectively, in the experimental yoghurts. Despite the quantitative importance of medium- and long-chain FFAs, they are not the main contributors to flavor of dairy products (Molimard and Spinnler, 1996).

The content of benzoic acid of yoghurts showed significant differences between the brands $(\mathrm{P}<0.05)$. The levels of benzoic acid were higher than value reported earlier for goat milk yoghurt (Guler, 2007), whereas were lower than levels reported by Tamime and Robinson (2001). This may be due to the type of milk and starter culture used for yoghurt. As known, benzoic acid formed from breakdown of hippuric acid by yoghurt organisms acts as a natural preservative. Benzoic acid and ethanoic acid were grouped in the same principal component (PC3) (Table 3). These acids may occur from the similar sources.

\subsection{Profiles of Volatile Compounds}

In volatile compounds analysis, the headspace analysis method is more convenient than the ether extract one (Kang et al., 1988). Of headspace methods, static headspace is the most satisfactory for quantification of acetaldehyde, acetoin, 2-butanone and 2-pentanone (Ott et al., 1999). The main aroma compounds identified in typical Turkish yoghurts are shown in Table 4. Except for acetaldehyde, all the other volatiles were not detected in some yoghurt samples. Quantitatively, the major volatile compound in the headspace and contributing to the flavor of set-type yoghurt appeared to be acetaldehyde, which was reported by other researchers (Kneifel et al.,1992; Ott et al., 1997). Significant $(\mathrm{P}<0.001)$ variations were observed in acetaldehyde concentrations of yoghurts among the brands. The mean concentration of acetaldehyde was $50.74 \mathrm{ppm}$. Acetaldehyde was positively correlated to protein $(0.314, \mathrm{P}<0.05)$ and titratable acidity $(0.350, \mathrm{P}<0.05)$ since the fortification and heat treatment of milk have been reported to increase the production of acetaldehyde (Tamime and Robinson, 2001). This increase in acetaldehyde may subsequently elevate free amino acids and growth factors for lactobacilli. Ketones are common constituents of yoghurt as other volatile compounds. However, some methyl ketones were not detected in all the yoghurts (Table 4). Even though diketone diacetyl (2,3 butanedione) was significantly varied from sample to sample ( $\mathrm{P}<0.001)$, it was detected in yoghurt samples of brands AS, IC, PN and TV. Diacetyl content showed significant correlations to levels of titratable acidity $(-0.539, \mathrm{P}<0.01)$, acetaldehyde $(-0.365, \mathrm{P}<0.05)$, ethanoic acid $(-0.351, \mathrm{P}<$ $0.05)$, octanoic $(0.493, \mathrm{P}<0.01)$ and decanoic $(0.513$, $\mathrm{P}<0.01)$ acids. The similar results were observed by Kneifel et al. (1992), Ulbert and Kneifel (1992) and Serra et al. (2009). Monnet and Corrieu, (2007) indicated that diketones in yoghurt come only from pyruvate, since thermophilic starter cultures are not able to metabolize citrate. S. thermophilus strains possess an $\alpha$-acetolactate synthase and an acetohydroxy acid synthase, which produce $\alpha$-acetolactate 
Table 4. Profiles of concentrations ( $\mu \mathrm{g} 100 \mathrm{~g}^{-1}$ of yoghurt) of mean volatile compounds of 10 brands of commercial set-type Turkish yoghurts ${ }^{1}$.

\begin{tabular}{|c|c|c|c|c|c|c|c|c|c|c|c|}
\hline \multirow[b]{2}{*}{ Volatiles } & \multicolumn{11}{|c|}{ Brands } \\
\hline & $\mathrm{AK}$ & AS & $\mathrm{DN}$ & DS & IC & PN & SK & ST & $\mathrm{TV}$ & YR & $\mathrm{P}$ \\
\hline Acetaldehyde ${ }^{1}$ & $\begin{array}{l}50.23 \\
\pm 7.78 \mathrm{a}\end{array}$ & $\begin{array}{l}53.55 \\
\pm 5.14 \mathrm{a}\end{array}$ & $\begin{array}{l}47.25 \\
\pm 3.34 \mathrm{a}\end{array}$ & $\begin{array}{l}56.03 \\
\pm 5.56 \mathrm{ab}\end{array}$ & $\begin{array}{l}55.40 \\
\pm 15.76 \mathrm{ab}\end{array}$ & $\begin{array}{l}40.50 \\
\pm 16.25 \mathrm{a}\end{array}$ & $\begin{array}{l}50.35 \\
\pm 24.47 \mathrm{a}\end{array}$ & $\begin{array}{l}39.60 \\
\pm 12.13 \mathrm{a}\end{array}$ & $\begin{array}{l}72.73 \\
\pm 2.05 \mathrm{~b}\end{array}$ & $\begin{array}{l}41.65 \\
\pm 3.00 \mathrm{a}\end{array}$ & $*$ \\
\hline Diacetyl $^{1}$ & $\begin{array}{l}3.33 \\
\pm 0.35 \mathrm{~b}\end{array}$ & nd & $\begin{array}{l}10.81 \\
\pm 0.14 \mathrm{e}\end{array}$ & $\begin{array}{l}3.37 \\
\pm 0.51 \mathrm{~b}\end{array}$ & nd & nd & $\begin{array}{l}4.34 \\
\pm 0.27 \mathrm{c}\end{array}$ & $\begin{array}{l}7.90 \\
\pm 0.09 \mathrm{~d}\end{array}$ & nd & $1.10 \mathrm{a}$ & ** \\
\hline Acetoin $^{1}$ & $\begin{array}{l}8.75 \\
\pm 2.03 \mathrm{~cd}\end{array}$ & nd & $\begin{array}{l}6.26 \\
\pm 0.22 \mathrm{bc}\end{array}$ & $\begin{array}{l}3.63 \\
\pm 0.30 \mathrm{a}\end{array}$ & $5.58 \pm 0.88 b$ & $\begin{array}{l}4.20 \\
\pm 0.22 \mathrm{a}\end{array}$ & $\begin{array}{l}5.75 \\
\pm 1.55 \mathrm{~b}\end{array}$ & nd & $\begin{array}{l}7.53 \\
\pm 0.78 \mathrm{c}\end{array}$ & $\begin{array}{l}12.79 \\
\pm 0.57 \mathrm{~d}\end{array}$ & $* *$ \\
\hline Acetone $^{1}$ & $\begin{array}{l}5.13 \\
\pm 0.22 \mathrm{ab}\end{array}$ & nd & $\begin{array}{l}5.35 \\
\pm 0.23 \mathrm{ab}\end{array}$ & $\begin{array}{l}5.01 \\
\pm 0.74 \mathrm{ab}\end{array}$ & $\begin{array}{l}9.32 \\
\pm 0.74 \mathrm{~d}\end{array}$ & $\begin{array}{l}14.10 \\
\pm 1.64 \mathrm{e}\end{array}$ & $\begin{array}{l}6.25 \\
\pm 1.30 \mathrm{bc}\end{array}$ & $\begin{array}{l}4.40 \\
\pm 0.64 \mathrm{a}\end{array}$ & $\begin{array}{l}5.63 \\
\pm 0.35 \mathrm{ab}\end{array}$ & $\begin{array}{l}6.73 \\
\pm 0.77 \mathrm{c}\end{array}$ & $* *$ \\
\hline Ethanol $^{1}$ & nd & $\begin{array}{l}9.15 \\
\pm 0.19 \mathrm{e}\end{array}$ & $\begin{array}{l}5.14 \\
\pm 0.20 \mathrm{c}\end{array}$ & $\begin{array}{l}3.90 \\
\pm 0.29 b\end{array}$ & nd & $\begin{array}{l}5.20 \\
\pm 0.16 \mathrm{c}\end{array}$ & nd & $\begin{array}{l}4.23 \\
\pm 0.27 \mathrm{~b}\end{array}$ & $\begin{array}{l}8.12 \\
\pm 0.52 \mathrm{~d}\end{array}$ & $\begin{array}{l}2.86 \\
\pm 0.38 \mathrm{a}\end{array}$ & $* *$ \\
\hline 2-Butanone ${ }^{2}$ & nd & nd & nd & nd & nd & nd & nd & nd & $\begin{array}{l}4.45 \\
\pm 1.05\end{array}$ & nd & - \\
\hline 2-Nanonane ${ }^{2}$ & nd & $\begin{array}{l}2.73 \\
\pm 0.47\end{array}$ & nd & nd & nd & nd & nd & nd & nd & nd & - \\
\hline 2-Undecanone ${ }^{2}$ & nd & $\begin{array}{l}9.50 \\
\pm 0.91 \mathrm{e}\end{array}$ & $\begin{array}{l}3.00 \\
\pm 0.41 \mathrm{~b}\end{array}$ & nd & $\begin{array}{l}1.71 \\
\pm 0.19\end{array}$ & $\begin{array}{l}5.46 \\
\pm 0.35 \mathrm{c}\end{array}$ & $\begin{array}{l}0.59 \\
\pm 0.08 \mathrm{a}\end{array}$ & $\begin{array}{l}10.60 \\
\pm 0.49 \mathrm{f}\end{array}$ & nd & $\begin{array}{l}6.56 \\
\pm 0.90 \mathrm{~d}\end{array}$ & ** \\
\hline 2-Tridecanone ${ }^{2}$ & nd & $\begin{array}{l}6.15 \\
\pm 0.13 \mathrm{e}\end{array}$ & $\begin{array}{l}2.56 \\
\pm 0.13 \mathrm{c}\end{array}$ & nd & $\begin{array}{l}1.41 \\
\pm 0.31 b\end{array}$ & $\begin{array}{l}5.20 \\
\pm 0.28\end{array}$ & nd & $\begin{array}{l}3.50 \\
\pm 0.20 \mathrm{~d}\end{array}$ & nd & $\begin{array}{l}0.65 \\
\pm 0.21 \mathrm{a}\end{array}$ & * \\
\hline 2-Pentadecanone ${ }^{2}$ & nd & $\begin{array}{l}10.71 \\
\pm 0.63 \mathrm{f}\end{array}$ & $\begin{array}{l}5.23 \\
\pm 0.19 \mathrm{~d}\end{array}$ & $\begin{array}{l}0.90 \\
\pm 0.29 \mathrm{a}\end{array}$ & $\begin{array}{l}2.13 \\
\pm 0.10 \mathrm{~b}\end{array}$ & $\begin{array}{l}2.65 \\
\pm 0.12 \mathrm{c}\end{array}$ & $\begin{array}{l}5.50 \\
\pm 0.37 \mathrm{~d}\end{array}$ & $\begin{array}{l}6.87 \\
\pm 0.38 \mathrm{e}\end{array}$ & nd & $\begin{array}{l}1.95 \\
\pm 0.37 \mathrm{~b}\end{array}$ & * \\
\hline Ethylacetate $^{1}$ & $\begin{array}{l}8.67 \\
\pm 1.03 \mathrm{~d}\end{array}$ & nd & $\begin{array}{l}5.95 \\
\pm 0.66 \mathrm{c}\end{array}$ & $\begin{array}{l}2.13 \\
\pm 0.25 \mathrm{a}\end{array}$ & $\begin{array}{l}2.35 \\
\pm 0.30 \mathrm{a}\end{array}$ & $\begin{array}{l}3.57 \\
\pm 0.22 \mathrm{~b}\end{array}$ & $\begin{array}{l}8.55 \\
\pm 0.36 \mathrm{~d}\end{array}$ & nd & $\begin{array}{l}3.13 \\
\pm 0.07 \mathrm{~b}\end{array}$ & $\begin{array}{l}2.24 \\
\pm 0.57 \mathrm{a}\end{array}$ & $* *$ \\
\hline
\end{tabular}

${ }^{1}$ Each observation is mean \pm standard deviation of four yoghurt samples; ${ }^{\text {a.b.c }}$ Means with different superscript within the same row were significantly different between yoghurt brands; $\mathrm{P}$ : significance level; NS: non-significant; $* \mathrm{P}<0.05$, $* * \mathrm{P}<0.01$, and $* * * \mathrm{P}<0.001$.

and 2-hydroxyacetolactate, respectively from pyruvate. These two $\alpha$-aceto acids are generally metabolized into more neutral compounds to maintain $\mathrm{pH}$ homeostasis (Tsau et al., 1992) by spontaneous decarboxylation. They can be converted into diacetyl, or by means of enzymatic mechanisms into branched-chain amino acids such as valine, leucine or isoleucine (Monnet and Corrieu, 2007). The former amino acids have been described as essential for $L$. delbrueckii subsp. bulgaricus responsible for development of acidity (Ott et al., 2000). These observations could explain why diacetyl was negatively correlated to titratable acidity, ethanoic acid and acetaldehyde as mentioned above. On the other hand, diacetyl was negatively correlated $(-0.322, \mathrm{P}<0.05)$ to acetoin, as reported earlier (Warsy, 1983). This may be due to the reduction of diacetyl to acetoin. Urbach (1995) reported that diacetyl can be reduced to acetoin by the starter bacteria, but its subsequent reduction to butan-2-one is brought about by the non starter lactic acid bacteria (NSLAB). Therefore, the high concentrations of ethanol and 2-butanone found in yoghurt from brand TV could be attributed to the presence of the non starter lactic acid bacteria (NSLAB), although microbial analyses were not done in yoghurts. This observation confirmed that 2-butanone was positively and negatively correlated to ethanol $(0.342, \mathrm{P}<0.05)$ and butanoic acid $(-0.497, \mathrm{P}$ $<0.01)$, respectively.
There were significant differences in acetone (2-propanone) concentrations in yoghurts $(\mathrm{P}<0.001)$. This methyl ketone is derived from $\beta$-oxidation of saturated free fatty acids depending on the lipolytic activity of yoghurt strains (Tsau et al., 1992). These observations could be explained why the saturated free fatty acids such as butanoic $(-0.493, \mathrm{P}<0.01)$ and hexanoic $(-0.396, \mathrm{P}<0.05)$ were inversely correlated to acetone. With respect to the other ketones, the amounts of 2-nonanone $(0.836, \mathrm{P}<0.01)$ 2-undecanone $(0.328, \mathrm{P}<$ $0.05)$ 2-tridecanone $(0.460, \mathrm{P}<0.01)$ and 2 -pentadecanone $(0.460, \mathrm{P}<0.01)$ showed a positive correlation with fat contents of yoghurts. Stelios et al. (2007) found that these ketones increased in yoghurts depending on the increase in fat content and storage time.

The other volatile compounds such as ethanol and ethyl acetate showed significant differences among yoghurts $(\mathrm{P}<0.01)$. Ethanol was correlated to acetoin $(-0.382, \mathrm{P}<0.05)$ and acetone $(-0.322, \mathrm{P}<0.05)$ and ethyl acetate $(-0.562, \mathrm{P}<0.01)$, lactose $(-0.409, \mathrm{P}<0.01)$ $\mathrm{pH}(-0.383, \mathrm{P}<0.05)$, fat $(0.581, \mathrm{P}<0.01)$. These findings were similar to the results reported by Kaminarides et al. (2007). Ethyl acetate was also correlated to acetoin (0.469, $\mathrm{P}<0.01)$, 2-nanonane $(-0.412, \mathrm{P}<0.01)$, 2-undecanone $(-0.722, \mathrm{P}<0.01)$, and 2-pentadecanone $(-0.390, \mathrm{P}<0.05)$. This observation confirmed that these ketones decreased in products with progressive storage 
since ethyl acetate is increased in yoghurts depending to time of storage (Güler, 2007). Ethyl acetate was negatively correlated to ethanoic acid $(0.305, \mathrm{P}<0.05)$, butanoic $(0.361, \mathrm{P}<0.05)$, hexanoic $(0.441, \mathrm{P}<0.01)$, octanoic $(0.358, \mathrm{P}<0.05)$ and decanoic $(0.341, \mathrm{P}<0.05)$ acids. As has been known, ethyl acetate comes from esterification of ethanol with acetyl-coenzyme A.

Principal component analyses (PCA) applied to volatile compounds is shown in Table 5. Four components explained $82.02 \%$ of total variation with $15.58 \%$ loss of variance (Table 5). The first component, accounting for $29.05 \%$ of total variance, was defined by acetoin and acetone in negative coefficient, as opposed to 2-nanonane, 2-undecanone, 2-tridecanone, 2-pentadecanone with positive coefficients that are ketones made up one group. In other words, acetoin and acetone were inversely related to the ketones mentioned. The second component (PC2), accounting for $22.99 \%$ of total variance, was mainly related to acetaldehyde, ethanol and 2-butanone with positive coefficient. This result confirmed that acetaldehyde, ethanol and 2-butanone are produced by lactic acid bacteria from lactose fermentation or amino acid catabolism (Molimard and Spinnler, 1996). The similar observations were made by Ulbert and Kneifel (1992). On the other hand, alcohol dehydrogenase does not seem to be involved in the reduction of acetaldehyde concentration as reported previously (Ott et al., 1999). The third component, explaining $18.57 \%$ of total variance, by ethyl acetate. The last component, responsible for $11.5 \%$ of variance, was related to was characterized by ethyl acetate. The last component, responsible for $11.5 \%$ of variance, was related to diacetyl. These results suggest that the occurrence of diacetyl and ethyl acetate may be different from the other volatiles as mentioned above.

Table 5. Principle component loadings of each volatile compound in yoghurts following varimax rotation.

\begin{tabular}{lcccc}
\hline & \multicolumn{4}{c}{ Principal Component } \\
\hline Volatiles & PC1 & PC2 & PC3 & PC4 \\
\hline Acetaldehyde & -0.12 & $\mathbf{0 . 7 4}$ & 0.40 & -0.03 \\
Acetoin & $\mathbf{- 0 . 7 2}$ & -0.10 & 0.09 & 0.36 \\
Acetone & $-\mathbf{0 . 5 8}$ & -0.13 & -0.56 & -0.39 \\
Diacety & 0.00 & -0.66 & 0.12 & $\mathbf{0 . 6 9}$ \\
Ethanol & 0.57 & $\mathbf{0 . 5 9}$ & -0.23 & 0.32 \\
2-Butanone & -0.23 & $\mathbf{0 . 8 1}$ & 0.03 & 0.32 \\
2-Nanonane & $\mathbf{0 . 8 3}$ & 0.24 & 0.16 & -0.16 \\
2-Undecanone & $\mathbf{0 . 7 8}$ & -0.24 & -0.44 & 0.17 \\
2-Tridecanone & $\mathbf{0 . 7 9}$ & -0.23 & 0.44 & -0.13 \\
2-Pentadecanone & $\mathbf{0 . 9 3}$ & -0.23 & 0.15 & -0.07 \\
Ethyl acetate & -0.59 & -0.29 & $\mathbf{0 . 6 1}$ & -0.15 \\
\% explained variance & 29.05 & 22.99 & 18.57 & 11.50 \\
\hline
\end{tabular}

Numbers in bold are primary importance due to the magnitude of coefficient.
In overall, the concentrations of volatile compounds such as acetaldehyde, acetone and acetoin in the yoghurts of this study were similar to the mean values reported by Ozer et al. (2007) and Güler et al. (2009), whereas the amount of ethanol was low. These authors did not find diacetyl in yoghurts. The levels of diacetyl ranged from less than 1 ppm (Ulbert and Kneifel, 1992; Ligor et al., 2008) up to more than $40 \mathrm{ppm}$ (Macciola et al., 2008). The amount of 2-butanone was similar to that obtained by Stelios et al., (2007) for yoghurt made from ovine milk. Kneifel et al.(1992) and Xanthopoulos et al. (1994) showed that the levels of acetaldehyde (2.0 to $41.0 \mathrm{ppm})$, diacetyl (0.2 to $2.3 \mathrm{ppm})$, acetoin (2.2 to 28.2), ethanol (0.2 to $9.9 \mathrm{ppm})$, acetone (1.8 to $3.4 \mathrm{ppm}$ ), and butanone-2 (0.1 - $0.6 \mathrm{ppm})$ as their samples had a wide variation in yoghurts. Discrepancies between studies might have been resulted from the factors including the use of different starters, synergistic effects of the microflora itself, fermentation conditions, protein used for increasing the dry matter or fat content of yoghurt, and milks from different mammalian species. Furthermore, the analytical method applied may also be a source of divergent volatile compounds concentrations.

\section{CONCLUSIONS}

This study confirmed that significant differences exist in physcochemical indices, volatile compounds and free fatty acids composition among different brands of Turkish commercial set-type yoghurt. Gas chromatographic analysis of the yoghurts can also easily be adapted to quality control or shelf-life studies of yoghurt. Acetaldehyde was predominant volatile compound in yoghurts, followed by acetone, acetoin, diacetyl and ethanol. Diacetly was negatively correlated to titratable acidity, acetaldehyde and ethanoic acid. Acetone was inversely correlated to the saturated free fatty acids such as butanoic and hexanoic. With respect to the other ketones, the amounts of 2-nonanone, 2-undecanone, 2-tridecanone and 2-pentadecanone showed positive and negative correlations with fat and ethyl acetate contents of yoghurts. It was found that ethanoic (acetic) acid was the most abundant in yoghurts among short chain free fatty acids. In addition, hexanoic, octanoic and butanoic acids showed the next high levels of short chain free fatty acids in the popular 10 brands of the Turkish commercial yoghurt products. These differences in volatile compounds and free fatty acids compositions as well as physico-chemical properties characterized in this study may applicable for estimation of flavor, nutritional value, quality control or shelf-life of the commmercial set-type Turkish yoghurts, and other yoghurt products.

\section{ACKNOWLEDGEMENTS}

This work was supported by the T.R. Prime Ministry State Planning 
Organization (DPT) project (Project no: 02 K 120860), and the authors gratefully acknowledge the GC-MS provided by the DPT project. The authors are also thankful to Ersin Gök and Gökan Diler for their assistance in conducting the experiments at the Food Engineering Department, Mustafa Kemal University, Hatay, Turkey.

\section{REFERENCES}

[1] AOAC. (2003) Official Methods of Analysis. Vol.I.17th ed. Association of Analytical Washington, DC, USA

[2] Beshkova, D., Simova, E., Frengova, G. and Simov, Z. (1998) Production of flavour compounds by yogurt starter cultures. J. Ind. Micro. Biotechn. 20: 180-186.

[3] Calderon, I., De Peters, E. J., Smith, N. E. and Franke, A. A. (1984) Composition of goat's milk: Changes within milking and effects of a high concentrate diet. J. Dairy Sci. 67: 1905-1911.

[4] Deeth, H. C., Fitz-Gerald, C. H. and Snow, A. J. (1983) A gas chromatographic method for the quantitative determination of free fatty acids in milk and milk products. New Zealand J. Dairy Sci. and Techn. 18: 13-20.

[5] FAO (2006) Food Agricultural Organization. www.faostat.fao.org

[6] Güler, Z. (2007) Changes in salted yoghurt during storage. Int. J. Food Sci. and Techn. 42: 235-237.

[7] Güler Z. (2008) Evaluation of lipolysis in set-type fermented milks made with different commercial yogurt starter cultures during storage. Milchwissenchaft. 33: 73-77.

[8] Güler,Z. and Park, Y.W. (2009) Evaluation of chemical and color index characteristics of goat milk, its yoghurt and salted yoghurt. Trop. and Subt. Agroecosystems, 11: 37-39.

[9] Güler, Z., Taşdelen, A., Şenol, H., Kerimoğlu, N., Temel, U. (2009) The determination of volatile compounds in set-type yoghurts by using static headspace gas chromatographic method, Turkish J. Food. 34 (3): 137-142.

[10] Hekmat, S. and McMahon, D. (1997) Manufacture and quality of iron fortified yoghurt. J. Dairy Sci. 80: 3114.

[11] Hassan, A.N., Ipsen, R., Janzen, T. and Qvist, K.B. (2003) Microstructure and rheology of yoghurt made with cultures different only in their ability to procedure exopolysaccharides. J. Dairy Sci. 86: 1632-1638.

[12] Hutchings, J.B. 1999. In: Food Color Appearance. $2^{\text {nd }}$ Ed. Springer, 610 pages.

[13] Kaminerides, S., Stamou, P. and Massouras, T. (2007) Comparison of the characteristics of set type yoghurt made from ovine milk of different fat content. Int. J. Food Sci. and Techn. 42:1019-1028.

[14] Kang, Y., Frank, J.F. and Lillard, D.A. (1988) Gas chromatographic detection of yoghurt flavour compounds and changes during refrigerated storage. Cul. Dairy Prod. J. 11: 6-9.

[15] Kneifel, W., Ulbert, F., Erhard, F. and Jaros, D. (1992) Aroma profiles and sensory properties of yoghurt and yoghurt related products. I. Screening of commercially available starter cultures. Milchwissenchaft. 47: 362-365.

[16] Lee, J.H., Melton, S. L., Waller, J. C. and Saxton, A. M. (2004) Modification of physicochemical characteristics of goat milk fat by feeding protected high oleic sunflower oil supplements. J. Food Sci. 69: 280-286.
[17] Ligor, M., Jarmalaviciene, R., Szumski, M., Marugka, A. and Buszewski, B. (2008) Determination of volatile and non-volatile products of milk fermentation processes using capillary zone electrophoresis and solid phase microextraction coupled to gas chromatography. J. Sept. Sci. 31: $2707-2713$

[18] Macciola, V., Candela, G. and De Leonardis, A. (2008) Rapid gas-chromatographic method for the determination of diacetyl in milk, fermented milk and butter. Food Control. 19: 873-878.

[19] Molimard, P. and Spinnler, H.E. (1996) Compound Involved in the Flavor of Surface Mold-Ripened Cheeses: Origins and Properties. J. Dairy Sci.79: 169-184.

[20] Monnet, C. and Corrieu, G. (2007) Selection and properties of [alpha]-acetolactate decarboxylase-deficient spontaneous mutants of Streptococcus thermophilus. Food Microbiology. 24 : 601-606.

[21] Ott, A. and Fay, L.B., Chaintreau, A.(1997) Determination and origin of the aroma impact compounds of flavour. J. Agric. and Food Chem. 45: 850-858.

[22] Ott, A., Germond, J.E., Baumgartner, M. and Chaintreau, A. (1999) Aroma comparisons of traditional and mild yogurts: headspacegas chromatography quantification of volatiles and origin of $\alpha$-diketons. J. Agric. Food Chem. 47: 2379-2385.

[23] Ott, A., Germond, J.E. and Chaintreau, A., (2000) Vicinal diketone dormation in yoghurt: $13 \mathrm{C}$ precursors and effect of branched-chain amino acids. J. Agric. and Food Chem. 48: 724-731.

[24] Park, Y.W. (1994) Basic nutrient and mineral composition of commercial goat milk

[25] yogurt produced in the U.S. Small Rumin. Res. 13: 63-70

[26] Ozer, B., Kirmaci, H.A., Oztekin, Ş., Hayaloglu,A. and Atamer, M. (2007) Incorporation of microbial transglutaminase into non-fat yogurt production, Int. Dairy J. 17: 199-207.

[27] Rasic, J.L. and Kurman, J.A. (1978) Yoghurt. Volume I, Technical Dairy Publishing House. Copenhagen, Denmark.

[28] Serra, M., Trujillo, A.J., Guamis, B. and Ferragut, V. (2009) Flavour profiles and survival of starter cultures of yoghurt produced from high-pressure homogenized milk. Int. Dairy J. 19: 100-106.

[29] Stelios, K., Stamou, P. and Massouras, T. (2007) Comparision of The Characterstics of Set Type Yohurt Made From Ovine Milk of Different Fat Content. International J. Food Sci. and Techn. 42: 1019-1028.

[30] Tamime, A. and Deeth, H. (1980) Yogurt: Technology and Biochemistry. J. Food Protect. 43: 939-977.

[31] Tamime, A.Y., Robinson, R.K. (2001) Yoghurt Science and Technology. CRC Pres. New York, US.

[32] TSI (2006) Yogurt. TS 1330. Ankara : Turkish Standar Institution.

[33] Tsau, J.L., Guffanti, A.A. and Montville, T.J. (1992) Convertion of pyruvate to acetoin helps to mantain $\mathrm{pH}$ homeostasis in Lactobacillus plantarum. Appl. and Envirom. Microbi. 58: 991-994.

[34] Ulbert, F. and Kneifel, W. (1992) Aroma profiles and sensory properties of yoghurt and yoghurt-related products. II. Classification of starter cultures by means of cluster analysis. Milchwissenchaft. 47: 432-434.

[35] Urbach, G. (1995) Contribution of lactic acid bacteria to 
flavour compound formation of dairy products. International Dairy Journal, 5, 877-903.

[36] Vargas, M., Chafer, M., Albors, A., Chiral, A. and Gonzalez-Martınez, C. (2008) Physicochemical and sensory characteristics of yoghurt produced from mixtures of cows' and goats' milk. Int. Dairy J. 18: 1146-1152.
[37] Warsy, J.D. (1983) Production of volatile aroma compounds in Dahi. J. Agric. Res. 21 (1): 31-36

[38] Xanthopoulos, V., Picque, D., Basit, N., Boquien, C.Y. and Corrieu, G. (1994) Methods for the determination of aroma compounds in dairy products: a comparative study. J. Dairy Res. 61: 289-297. 